УДК 903.22(477.85)

ТЕРСЬКИЙ С. В.

https://orcid.org/ 0000-0003-0177-8087

https://doi.org/10.33577/2313-5603.36.2021.111-122

\title{
ОБОРОННИЙ КОМПЛЕКС ЛІТОПИСНОГО ЗВЕНИГОРОДА
}

Один із головних політичних центрів Галицького князівства - Звенигород, розташований поблизу галицько-волинського кордону на перетині стратегічних шляхів протягом XI - XIII ст. відігравав важливу роль у військово-політичних подіях. На полях поряд із Звенигородом відбулося принаймні декілька великих битв за володіння Галичиною. Три битви - 1226, 1144 та 1227 рр. знайшли відображення в літописах. Однак конкретний перебіг цих подій доволі скупо відображений в писемних джерелах. В статті проаналізовано військово-топографічну ситуацію на території Звенигородського князівства. Простежено роль укріплень Звенигорода на основних стратегічних шляхах, які перетиналися в цьому місці та вели до основних центрів Галицького та Волинського князівств.

Сьогодні літописний центр князівства локалізований на території однойменного села біля Львова. В статті підбито підсумки багаторічних археологічних досліджень із вивчення військової інфраструктури X-XIII ст. в цьому районі. Враховано результати найновіших археологічних розвідок на території Звенигородського князівства. Проведеними роботами встановлено датування решток давніх фортець. Проаналізовано числені знахідки середньовічного озброєння, які додатково ілюструють стан військової інфраструктури літописного Звенигорода.

Ключові слова: мережа укріплень, оборонне будівництво, військово-політична ситуація, Звенигород, Галицько-Волинська держава.

Актуальність теми визначається тим, що військова інфраструктура княжих столиць була важливою частиною військової інфраструктури окремих земель-князівств Русі. У зв’язку із міжусобними війнами, які регулярно спустошували українські землі в XI - XIII ст., описи укріплень княжих столиць порівняно часто потрапляли на сторінки писемних джерел Особливо багатими на військові конфлікти в XI-XIII ст. були околиці Звенигорода поблизу галицько-волинського прикордоння. Це було пов'язано із раннім відокремленням (кінець в XI ст.) Галицького князівства із складу Київської держави. Питання локалізації літописного Звенигорода були розв'язані ще істориками XIX ст. (В. Ільницький, М. Грушевський). Протягом XX XXI ст. на укріпленій за княжої доби території літописного

Терський Святослав Володимирович, доктор історичних наук, професор, професор кафедри історії, музеєзнавства і культурної спадщини Національного університету «Львівська політехніка»

(C) Терський С. В., 2021 
міста проведені наймасштабніші на Заході України археологічні дослідження, які дозволили визначити історичні етапи розвитку оборонних укріплень Звенигорода. Перший підсумок археологічних розкопок літописної столиці Опілля було підбито ще в 1981 р., у дисертаційному дослідженні $\mathrm{B}$. Шеломенцева-Терського. Однак ці матеріали в значній мірі залишилися неопублікованими. Наступний огляд результатів всіх археологічних робіт на території Звенигорода та Звенигородського князівства побачив світ у 2015 р. (Шеломениев-Терский, 1981; Гупало, 2014).

Однак, поза межами згаданих публікацій досі залишаються багаті колекції Львівського історичного музею. Матеріали зібрані у Звенигороді та його околиці. Лише у фондовій групі «Київська Русь» їх кількість досягає близько 10 тисяч одиниць збереження.

Новизна дослідження. В даній статті автор на основі аналізу даних попередніх історичних та археологічних досліджень робить спробу окреслити процес формування оборонного комплексу літописного Звенигорода, як одного 3 центрів Галицького князівства у XI - XIII ст. Проаналізовано систему фортифікації центральної частини Звенигородського князівства, оглянуто колекції знахідок озброєння.

Метою статті є доповнення сучасних історичних досліджень військової справи в Галицько-Волинській державі аналізом основних складових оборонного комплексу літописного Звенигорода: системи фортифікацій і арсеналу дружинників та з'ясування на новій джерельній базі особливостей формування військової інфраструктури столиць Галицького князівства.

Виклад основного матеріалу дослідження. Звенигородська земля сформувалась близько рубежу X/XI ст. в процесі освоєння межиріччя басейнів рік Дністра та Західного Бугу великокнязівською владою. Відтак, Звенигород - літописний центр галицького Опілля - від моменту заснування був опорним пунктом Київської держави у новопридбаному Східному Прикарпатті. Отже, військовий сегмент у його топографічній структурі та присутність значної кількості дружинників серед його мешканців завжди були помітними його характеристиками.

Звенигород, що був столицею однойменного князівства, розташованого у басейнах лівобережних приток верхів’їв цих 
рік, неодноразово згадуваний у літописах протягом $1086-$ 1235 роках у зв'язку з різними військовими подіями.

Вже перша військова сутичка між перемишльським князем Ростислвом Рюриковичем та трьома тисячами руських і угорських воїнів на чолі з воєводою звенигородського князя Володимирка, які обороняли Звенигород у 1126 р., продемонструвала міцність міських укріплень. Їх нездоланність підтвердилася 1138 р.. коли біля міста таборував польський король Болеслав Кривоустий під час походу на Галич.

Значно складнішою для звенигородців була стратегічна ситуація під час боїв із великим київським князем Всеволодом у 1144 р. Під прикриттям ночі його війська побудували гаті через річку, “...w заоутра переидоша ргькоу и взАша горы за Володимеромъ” (Ипатьевская летопись, 1923: 315). Оточивши місто великий київський князь змусив звенигородського князя Володимирка до миру. Всеволод прийняв Володимирка у своєму таборі в шатрі, де той цілував хрест київському князеві й заплатив йому “за трудъ” 1400 гривень срібла. Помітну роль укріплення Звенигорода відіграли взимку 1227 р., коли угорський король Андрій II, вступив у межі Галичини на підтримку свого сина Андрія у боротьбі з Мстиславом Мстиславичем Удатним за галицький престол (Ипатьевская летопись, 1923: 740, 749).

Археологічно місто досліджується з 1886 р. Першими дослідниками міста були І. Шараневич, Л. Чачковський та Я. Пастернак. Згодом масштабні роботи проведені І. Свєшніковим, Г. Власовою, В. Шелом'янцевим-Терським, О. Ратичем та В. Гупало (Шелом'янцев-Терський, 1998).

Місто займало підвищення посеред болотистої річкової низовини поблизу витоків р. Білки. Дитинець площею близько 1,5 га зведений в XI ст. на природному підвищенні з ескарпованими схилами у південно-західній частині городища. У зовнішній конструкції вала, дослідженого розкопками у західній частині майданчика, виявлено рештки дерев'яних городень, а з внутрішнього боку - руїни житлових приміщень.

Східніше, на менш підвищеній ділянці, на 20 м нижче рівня дитинця на площі близько 10 га знаходився окольний город, який був відмежований від пригородів високим валом (уроч. 
Вали). Тут був громадський центр Звенигорода, по якому досліджено цілий ансамбль білокам'яних будівель, де поряд 3 князівським палацом, фундаментальною колоною і князівською усипальницею вимуровано й церкву.

Укріплення окольного города до нашого часу не збереглися. Розкопками встановлено факт перебудови первісних укріплень цієї частини Звенигорода (XI ст.), яка відбувалася не пізніше першої половини XII ст. При цьому знівелювали поверхню майданчика біля підніжжя ескарпу пагорба дитинця внаслідок чого було ліквідовано рештки старої найдавнішої забудови (т.зв. посад Загородище, площею близько 3 га). Вали цього часу на західній ділянці окольного города досліджувалися у 1963 - 1969 роках експедицією під керівництвом В. Шелом'янцева-Терського. Лінія оборони окольного города включала кріпосні стіни із городень і клітей з печами (Терський, 2014a: 38-42).

Додатково посилював систему оборони міста також наповнений водою рів, облаштований біля підніжжі ескарпованого схилу окольного города. На 4 м нижче від рівня окольного города до рову прилягала 3 зовнішнього боку третя лінія фортечних стін, що складалася із клітей і скісного частоколу. Суттєву природну перешкоду для ворога становили болотисті заплави численних потічків, які оточували передмістя із заходу, півдня і півночі. Загалом укріплення західної частини міста займали важливе місце у системі оборони Звенигорода.

Слід думати, звенигородська залога в час небезпеки мала б суттєво посилюватися ремісниками, які постійно проживали за межами укріплень Так, із заходу до Окольного города прилягав посад 3 рештками двох залізоплавильних горнів XII-XIII ст., частиною садиби шевця XI ст. і майстернею ремісникабронзоливарника початку XII ст., 3 північного сходу - посад площею близько 10 га, де була давня торговиця 3 дерев'яною церквою Параскеви П'ятниці.

Частина північно-східного посаду міста займала понижену ділянку, де у торфовому грунті добре збереглися дерев'яні конструкції та стародавні вироби 3 дерева і шкіри: дерев'яні миски, черпаки, ложки, дитячі іграшки, бондарські вироби, зразки шкіряного взуття. До унікальних знахідок належать дві 
сопілки, виготовлені з бузини. Від міських укріплень через цей посад пролягала вимощена деревом вулиця завширшки 5,1 м. Розчищено 70 м цієї вулиці. Вона складалася 3 поздовжніх лаг, перекритих поперечним настилом 3 колод. Тут відкрито залишки дерев'яних зрубів будинків, що укладаються у три головні будівельні періоди від кінця XI - до середини XII ст. Серед знахідок - бронзовий кістень, дві берестяні грамоти, свинцева печатка галицького князя Івана Васильковича (1140-1141рр.) тощо. Значну частину посаду займав квартал ювелірів, який, очевидно, мав свій храм.

Частина заміських храмів та монастирів, займаючи топографічно підвищені ділянки, могла мати власні укріплення і бути форпостами на підходах до Звенигорода. За наявними на сьогодні даними, у княжому Звенигороді і його пригородах до 1241 р. налічувалося щонайменше 12 церков та п'ять монастирів. На існування храмів вказують два кладовища XI -XII ст., досліджені в урочищах Гоєва гора і Загуменки.

Загальна площа центральної частини міста становила понад 25 га, а уся територія міста разом з передмістями з заходу на схід простягалася на 15 км, а 3 півночі на південь - не менше ніж на 7 км. На цій території досліджено численні ремісничі села, монастирища та садиби бояр. Похід монголів зупинив поступовий розвиток міста. Його жертви знайдені у заплаві старого річища Білки. Тут відкрито чимало людських кістяків під тонким шаром задернованого торфу, осторонь лежали черепи.

Розповісти про стан гарнізону міста може детальна фіксація всіх належних йому предметів військового спорядження та озброєння. Аналіз знахідок дружинного спорядження за окремими фортецями дозволяє скласти загальну картину суспільного та професійного рівня їх гарнізону та надає чимало важливої інформації для загальної характеристики фортеці.

У місті було налагоджено виробництво окремих видів озброєння. Зокрема, у напівземлянці майстра-костеріза знайдено напівфабрикат ударної зброї - кистеня (Фонди ЛІМ КР-8902).

Близько 90\% впорядкованих на сьогодні збірок з розкопок літописного Звенигорода знаходяться у групі фондів «Київська Русь» Львівського історичного музею. Це, насамперед, матеріали 
археологічних експедицій музею, що працювали у Звенигороді протягом 1950-1960-х роках під керівництвом або за участю Г. Власової та В. Шелом'яцева-Терського. Досить яскравою $є$ колекція знахідок, які раніше належали Культурно-історичному музею НТШ.

Свого роду «табельною» зброєю старшого дружинника був меч. У Звенигороді та в його околиці знайдено декілька частин мечів XI - XIII ст., які були статусною зброєю (Терський, 2013: 7, 10).

Проте, найбільш доступною та універсальною зброєю для широкого кола, як дружинників, так і міських ополченців був спис - зброя першого удару. Списоносці, зазвичай, складали основу піхоти. Але й для княжої кінної дружини спис був головною наступальною зброєю. У Звенигороді знайдено близько десятка залізних вістер списів (наприклад, фонди ЛIМ КР-8285, 36522).

Важливим видом зброї ближнього бою були також булави та кистені. Вони також могли мати вигляд статусного озброєння. Для цього їх виготовляли, переважно із бронзи та покривали черневими орнаментами (Терський, 2014: 9; 2018). У Звенигороді знайдено чотири різних типів кистенів, в т.ч. і найбільш демократичніші - рогові (Фонди ЛІМ КР-46310).

Озброєння дальнього бою представлене у Звенигороді та в околиці знахідкою понад півтори сотні вістер стріл різних типів, в т.ч. і кістяних, які використовувались, переважно, для полювання на хутрових звірів (Терський, 2012: 68, рис. 1).

Предмети спорядження вершника та верхового коня, насамперед, належали кінним дружинникам. Кінна дружина у давньоукраїнському війську складала основу авангарду. Про це свідчать численні знахідки, насамперед, залізних острог у напластуваннях найкраще вивчених городищ.

Спорядження кінного дружинника протягом X-XIV ст. пройшло тривалу еволюцію, про особливості якої свідчать знахідки предметів спорядження верхового коня (вудила, стремена, деталі сідла, прикраси збруї, попружні пряжки, застібки від пут i недоуздка, льодохідні шипи, підкови, шкребниці) та засоби керування (остроги, навершя руків'я батогів). Загалом, найчастіше трапляються знахідки ланок вудил, острог, а також металевих кілець, що могли використовуватися в кінській збруї. 
Управління конем здійснювалось за допомогою вуздечки. Її важливою частиною були вудила. Вони складаються 3 гризла (міжзуб'я) і бічних щелепних (прищічних) обмежувачів-псаліїв, що сприяли кращому управлінню конем. За особливістю форми та конструкцією їх поділяють на шість типів, з яких три набули поширення у Звенигороді.

До найраніших типів відносяться прості вудила, виготовлені 3 одного, інколи вигнутого округлого стрижня, завершеного 3 обох кінців петлями, через які просунуті рухомі кільця. Один екземпляр таких вудил виявлено під час розкопок в 1955 р. (Фонди ЛIМ КР-8235). Цей тип вудил (VI за А.М. Кірпічніковим) належить до запозичень від кочівників і датується, переважно, X - XI ст. (Кірпічніков, 1973: 17-18). В подальшому у вжитку переважали стандартні двоскладові вудила різної форми і розмірів 3 ланками довжиною від 3 до 16,5 см (Фонди ЛІМ КР-30170, 36533-36534 mа ін.). Кільця по краях для кріплення до вуздечки, діаметром 3-6 см, часто сильно витерті, очевидно від тривалого уживання.

У Звенигороді також знайдено дві кістяні застібки від кінських пут, в т.ч. одна 3 них - у перетині західного валу Окольного города (Терський-Шеломенцев, 1978: 90, рис. 6:13). Ці знахідки також мають чисельні аналоги у галицько-волинських містах (Терський, 2015: 80, рис. 3).

Відмінною рисою професійних кіннотників були остроги. Всього у Звенигороді зібрано понад 30 цілих і фрагментованих острог (Фонди ЛIМ КР-19321, 22809, 36547-36558 та ін.). Окремі 3 них мають округлі у перетині куполоподібні або конічні шипи. Приблизно третина острог мають гострі і прямокутні прорізні петлі (Терский-Шеломенцев, 1978: 213, мал. 3: 9, 10). Їхні скоби в основному горизонтальні та відповідають III типу острог XII XIII ст. за класифікацією А. М. Кірпічнікова (Кирпичников, 1973: 61, мал. 37). Аналогічні остроги мали значне поширення у інших галицько-волинських містах.

Стабільна відсутність парних острог у Звенигороді опосередковано підтверджує давнє припущення відомого дослідника городищ В.К. Гончарова, що вершники княжої доби могли користуватися лише однією острогою (Гончаров. 1950: 99). 
Різні типи острог часто визначали статус дружинника. Позолочену острогу з чотиригранним шипом невідомий селянин із Звенигорода знайшов при плануванні поверхні в ур. «Вали» та передав у Музей Наукового товариства імені Шевченка (Фонди ЛІМ КР 8268; Терський, 2015а: 112; Терський-Шеломенцев, 1978: 213, мал. 5, 10). Ще одна звенигородська острога була виготовлена з міді. Позолочені остроги мали поширення у дружинних центрах (дві були знайдені на Райковецкому городищі: Гончаров, 1950: 98) і, очевидно, належали князям або заможним боярам.

Унікальною знахідкою є мініатюрна, очевидно, дитяча острога (довжина кінців скоби дорівнює $7 \mathrm{~cm}$ ), зі слідами позолоти. Її знайдено в західній частині Окольного города в шарі XII - XIII ст. (Терський, 2018a: 6).

Також лише професійні кіннотники користувались стременами та підковували своїх коней. У Звенигороді знайдено декілька уламків стремен (Терский-Шеломенцев, 1978, рис. 5: 5-8) та близько двох десятків підков (в залежності від обставин їх знахідок не завжди можна відносити лише до Княжої доби) (Фонди ЛІМ КР-8266, 22678-22679, 36536-36537 та ін.). Одна 3 підков, найбільша, розмірами $15 \times 12$ см із шістьма прямокутними отворами і жолобком уздовж краю для голівок цвяхів. (Терский-Шеломенщев В.С., 1978: рис. 5, 6). Позаду вона має спеціальний виступ для того, щоб краще трималася і не з'їжджала 3 копита. Товщина підкови - 0,8 см. На одній 3 половинок в отворі зберігся загнутий знизу цвях на зразок сучасних цвяхіввухналів 3 вертикальною напівсферичною голівкою, очевидно для того, щоб голівки не стиралися і щоб підкова не сповзала (Терский-Шеломенцев, 1978: рис. 5, 5).

Важливим предметом догляду за конем були скребниці. Одна 3 них знайдена в західній частині Окольного города Звенигорода в культурному шарі кінця XI - поч. XII ст. (Терский-Шеломенцев, 1978: 215, рис. 5: 11). Робоча ऑï частина у формі прямокутна 20x30,5 см 3 нарізаними зубцями, а на кутах із завитками для прикраси. Довжина ручки 15,2 см. За типологією кінських скребниць з Новгорода їі можна віднести до другого типу (за А.Ф. Медведєвим). 
Ще один атрибут дружинників - шкіряний пояс - представлений трьома десятками поясних залізних пряжок. За формою вони поділяються на три типи: напівкруглої форми, прямокутні, круглі (овальні).

Висновки. Таким чином, комплекс археологічних джерел, збережених, переважно, у фондах Львівського історичного музею, розкриває важливі сторони оборонної інфраструктури літописного Звенигорода. Проаналізовані предмети озброєння та військового спорядження свідчать про перебування у місті структурованої дружинної спільноти. Разом 3 вивченими археологічно фортифікаційними спорудами ці предмети наочно демонструють важливе значення Звенигорода у військовій інфраструктурі Галицького князівства.

Кількість виявлених розкопками у Звенигороді та його околиці предметів озброєння та військового спорядження постійно зростає. Це відкриває можливості в майбутньому застосування методів статистичної обробки накопичених у музеях колекцій.

\section{Використані посилання}

Гончаров В. (1950) Райковеикое городище. Киев, 219 с.

Гупало В. (2014) Звенигород і Звенигородська земля у XI - XIII століттях (соиіоісторична реконструкиія). Львів, 532 с.

Ипатьевская летопись (1923) Полное собрание русских летописей. Т. 2. Петроград, $320 \mathrm{c}$.

Кирпичников А. (1973) Снаряжение всадника и верхового коня на Руси IX-XIII вв. Ленинград, Наука. Свод археологических источников. Bыn. E 1-36.

Терский-Шеломенцев С. (1978) Исследования детинца Звенигорода Галицкого. Советская археология. № 1. С. 206-215.

Терський С. (2014) Археологія доби Галицько-Волинської держави. Київ, “Стародавній світ", 164 с.

Терський С. (2018) Роль археологічних експедицій Львівського історичного музею у дослідженні літописного Звенигорода. Музей - платформа суспільного діалогу. Матеріали Міжнародної науково-практичної конферениї до 125-річчя Львівського історичного музею (Львів, 5 жовтня 2018 р.). Львів, 3 - 9.

Терський С. (2012) Знахідки предметів озброєння X-XIII ст. на галицьковолинському пограниччі. Археологія \& фортифікаиія Середнього Подністров'я. Збірник матеріалів Другої Всеукраӥнської науково-практичної конференції. Кам'янець-Подільський, С. 68 - 72.

Терський С. (2013) Меч у Галицькому та Волинському князівствах (XI-перша пол. ХІІІ ст.). Вісник Наџіонального університету “Львівська політехніка”. № 752: Держава та армія. С. 5 - 13. 
Терський С. (2014) Кістень у Галицькому та Волинському князівствах (X-XIV ст.). Вісник Національного університету “Львівська політехніка". № 784: Держава та армія. С. 3 - 12 .

Терський С. (2015) Спорядження вершника та коня на Волині X-XIV ст. Львів, Культура і мистецтво західноукраӥнських земель 2009, 2010. Збірник статей, Національна академія наук України, Інститут українознавства імені Івана Крип'якевича, С. 71- 114.

Терський С. (2015) Матеріальна культура літописного Звенигорода у світлі фондової колекції Музею НТШ. Музеї Львова: події, колекиї, люди: матеріали науково-практичної конферениії, Львів, 24 - 25 жовтня 2013 року Львівський історичний музей. Львів, Апріорі. С. 108 - 118.

Терський С. (2018) Булави княжих дружин Галицько-волинських земель. Тези доповідей Третьої Міжнародної зброєзнавчої конферениії. 12-14 червня, 2018 року. Київ, Інститут історії НАНУ. С. 71-73.

Терський-Шелом'янцев В. (1978). Дослідження посаду літописного Звенигорода. Археологія. Вип. 28. С. 86-93.

Фонди Львівського історичного музею «Київська Русь».

Шелом' янцев-Терський В. (1998) 3 історії дослідження літописного Звенигорода. Записки Наукового Товариства ім. Шевченка. Т. 235. Праці археологічної комісіі. Львів, С. 358-372.

Шеломенцев-Терский В. (1981) Летописный Звенигород Галицкий XIII cm. Автореферат диссертации на соискание научной ступени кандидата исторических наук. Киев, Институт археологии АН УССР, 20 с.

\section{References}

Funds of the Lviv Historical Museum "Kyivan Rus'".

Goncharov V. (1950) Raikovets settlement. Kyiv, 219 p. (rus).

Gupalo V. (2014) Zvenyhorod and Zvenyhorod land in the XI-XIII centuries (socio-historical reconstruction). Lviv, 532 p. (ukr).

Ipatiev Chronicle (1923) The complete collection of Russian chronicles. T. 2. Petrograd, $320 \mathrm{p}$.

Kirpichnikov A. (1973) Equipment of a rider and a riding horse in Russia of the IX-XIII centuries. Leningrad, Nauka. In: Collection of archaeological sources. Issue. E 1-36 (rus.).

Shelomentsev-Tersky V. (1981) Chronicle Zvenigorod Galitsky XXIII century. Author's abstract of the dissertation on competition of a scientific degree of the candidate of historical sciences. Kyiv: Institute of Archaeology of the USSR Academy of Sciences, 20 p. (rus.).

Shelomyantsev-Tersky V. (1998) From the history of the study of the chronicle Zvenigorod. In Notes of the Scientific Society. Shevchenko. T. 235. Proceedings of the Archaeological Commission. Lviv, P. 358-372 (ukr.).

Tersky S. (2012) Finds of weapons of the X-XIII centuries on the GalicianVolyn border. In: Archeology \& fortification of Middle Transnistria. Proceedings of the Second All-Ukrainian scientific-practical conference. Kamenets-Podolsky. P. 68-72 (ukr.). 
Tersky S. (2013) Sword in the Galician and Volyn principalities (XI - first half of the XIII century). In: Bulletin of the National University "Lviv Polytechnic". № 752: State and Army. P. 5-13 (ukr.).

Tersky S. (2014) Kisten' in the Galician and Volyn principalities (X-XIV centuries). In: Bulletin of the National University «Lviv Polytechnic». № 784: State and Army. P. 3-12 (ukr.).

Tersky S. (2014a.) Archaeology of the Galicia-Volyn state. Kyiv, "Ancient World", 164 p. (ukr.).

Tersky S. (2015) Equipment of a rider and a horse in Volyn of the X-XIV centuries. Culture and art of western Ukrainian lands 2009, 2010. Collection of articles, National Academy of Sciences of Ukraine, Ivan Krypyakevych Institute of Ukrainian Studies. Lviv, P. 71-114 (ukr.).

Tersky S. (2015a) Material culture of the chronicle Zvenigorod in the light of the stock collection of the Museum of NTSh. Museums of Lviv: events, collections, people: materials of the scientific-practical conference, October 24-25, 2013. Lviv, Lviv Historical Museum, p. 108-118 (ukr.).

Tersky S. (2018) Maces of princely wives of Galicia-Volyn lands. In: Abstracts of the Third International Arms Conference. June 12-14, 2018. Kyiv, Institute of History of NASU. P. 71-73 (ukr.).

Tersky S. (2018a). The role of archaeological expeditions of the Lviv Historical Museum in the study of the chronicle Zvenigorod. The museum is a platform for public dialogue. Proceedings of the International Scientific and Practical Conference dedicated to the 125th anniversary of the Lviv Historical Museum, October 5, Lviv, p. 3-9 (ukr.).

Tersky-Shelomentsev S. (1978) Studies of the child Zvenigorod Galitsky. Soviet archeology. № 1. p. 206-215 (rus.).

Tersky-Shelomyantsev S. (1978) Research of the position of the chronicle Zvenigorod. Archaeology. Issue 28. P. 86-93 (ukr.).

\section{Terskyj S.}

\section{DEFENSE COMPLEX OF THE CHRONICLE ZVENYGOROD}

One of the main political centers of the Galician principality - Zvenyhorod, located near the Galician-Volyn border during the XI-XIII centuries. played an important role in military and political events. At least a few major battles between the then rulers of the city and their opponents took place in the fields near Zvenyhorod. Three battles - 1226, 1144 and 1227 were mentioned in the chronicles.

However, the specific course of these events is rather sparsely reflected in written sources. The military topographic situation on the territory of Zvenyhorod principality is analyzed. The role of Zvenyhorod fortifications on the main strategic roads that intersected in this place and led to the main centers of the Halych and Volyn principalities was traced.

Today the chronicle center of the principality is located on the territory of the village of the same name near Lviv. The results of many years of archaeological research on the study of military infrastructure of the X-XIII centuries are summarized. in 
this area. The results of the latest archeological excavations on the territory of the Zvenyhorod principality are taken into account. Archaeological excavations conducted by Volodymyr Shelomentsev-Tersky in 1962-1973 provided the most data on the defense infrastructure of Zvenyhorod.

The work established the dating of the remains of ancient fortresses. Numerous finds of medieval weapons are analyzed, which additionally illustrate the state of the military infrastructure of the chronicle Zvenyhorod. The Zvenyhorod garrison was well structured and equipped with military ammunition. The unique discovery of a children's spur indicates the early stages of preparation of young people for military service. Gilded spurs, apparently, belonged to military leaders - princes and great boyars.

Keywords: fortification network, defense construction, military-political situation, Zvenyhorod, Galicia-Volyn state. 